\title{
THE ANTICHOLESTEROL ACTIVITY OF BETULINIC ACID AND STIGMASTEROL ISOLATED FROM THE LEAVES OF SUNGKAI (PARONEMA CANESCENS JACK)
}

\author{
MUHARNI MUHARNI*, FERLINAHAYATI FERLINAHAYATI, HENI YOHANDINI, FAHMA RIYANTI, NADYA \\ ANASTASIA PRESCILLA PAKPAHAN
}

Department of Chemistry, Faculty of Mathematics and Natural Sciences, University of Sriwijaya, Indralaya, Ogan Ilir, South Sumatra, 30662 Indonesia

"Email: muharnimyd@yahoo.co.id

Received: 25 Nov 2020, Revised and Accepted: 12 Jan 2021

ABSTRACT

Objective: The purpose of this study was to evaluate the anticholesterol activity of Paronema canescens leaves extract.

Methods: These compounds were isolated via chromatography using silica gel as the stationary phase. Their structures were revealed using IR and 1D NMR data and by comparing their NMR data with the literature's data. The anticholesterol activity of compounds was tested using photometry via the Liebermann-Burchard reaction.

Results: Betulinic acid (1) and stigmasterol (2) were isolated from the leaves extracts of sungkai (P. canescens). The betulinic acid (1) that was isolated showed anticholesterol activity with an $\mathrm{IC}_{50}$ value of $60.53 \mu \mathrm{g} / \mathrm{ml}$, stigmasterol (2) $222.32 \mu \mathrm{g} / \mathrm{ml}$, while the standard anticholesterol compound simvastatin had an $\mathrm{IC}_{50}$ of $24.68 \mu \mathrm{g} / \mathrm{ml}$.

Conclusion: The stigmasterol (2) has previously been reported from P. canescens while that of betulinic acid (1) is reported here for the first time and identifies its anticholesterol activity.

Keywords: Paronema canescens, Betulinic acid, Anticholesterol

(c) 2021 The Authors. Published by Innovare Academic Sciences Pvt Ltd. This is an open access article under the CC BY license (https://creativecommons.org/licenses/by/4.0/) DOI: https://dx.doi.org/10.22159/ijap.2021v13i2.40372. Journal homepage: https://innovareacademics.in/journals/index.php/ijap

\section{INTRODUCTION}

P. canescens is commonly known as sungkai or jati barang. In Indonesia, this plant is found in South Sumatra, Lampung, Bengkulu, and Kalimantan. This plant's leaves have been used traditionally to cure fever, malaria, wounds, ringworm, and toothaches $[1,2]$. The water from the boiled stem bark of sungkai is used as a smallpox medicine [3]. In South Sumatra, Indonesia, the people of Musi Banyuasin use this plant to treat hypertension and high cholesterol (hyperlipidemia) [4]. Hypertension is one of the most common diseases in the world. One of the triggers for hypertension is a high level of cholesterol in the blood. Cholesterol is a fatty lipid produced by the liver and is crucial for normal body functioning. The cholesterol level in blood was influenced by several factors like nutrition, diet, weight, and including drugs consumed [5]. The buildup of cholesterol in the blood can cause the narrowing and stiffness of blood vessel walls, causing blood pressure to increase. Hypertension can lead to coronary heart disease and stroke [6, 7].

Several chemical contents and biological activities of P. canescens have been reported in the literature. The methanol extract from the leaves of $P$. canescens has been reported to have antibacterial activity [8]. The methanol extract from the leaves of $P$. canescens also contained alkaloid, terpenoid, steroid, flavonoid, and tannin [9]. The acetone extract from the leaves of $P$. canescens was reported to contain seven clerodane-type furanoditerpenoid compounds: peronemins $\mathrm{B} 2, \mathrm{~A} 2, \mathrm{~B} 3, \mathrm{~A} 3, \mathrm{Bl}, \mathrm{Cl}$, and $\mathrm{Dl}$, and caffeine acid glycosides were shown to have antimalarial activity. The acetone extract from the leaves of $P$. canescens has also been found to contain $\beta$-sitosterol, phytol, $\beta$-amyrin, peronemin, isopropanol, diterpenoids, acetonide, and flavonoid glycoside [10]. The methanol extract from the leaves of $P$. canescens was reported to have antibacterial activity. The leaves of $P$. canescens were also said to have weak antiplasmodial and cytotoxic activity [11] and to be useful as insecticides. However, no chemical studies have been reported regarding the anticholesterol activity of the leaves of $P$. canescens. Phytochemical test of the ethanol extract of the sungkai plant was positive for alkaloid, flavonoid, steroids, triterpenoid, glycoside, and phenol [12] Steroid, terpenoid, and phenol effect of reducing cholesterol level.
Therefore the purpose of this study was to evaluate the anticholesterol activity of $P$. canescens leaves extract.

\section{MATERIALS AND METHODS}

General experimental procedures

The IR $(\mathrm{KBr})$ spectrum was recorded on a Perkin Elmer-FTIR spectrometer. NMR spectra were recorded on an NMR JEOL JNM ECA-500 spectrometer $\left(500 \mathrm{MHz}\right.$ for ${ }^{1} \mathrm{H}$ NMR and $125 \mathrm{MHz}$ for ${ }^{13} \mathrm{C}$ NMR spectra) in $\mathrm{CD}_{3} \mathrm{OD}$ or $\mathrm{CDCl}_{3}$. UV-visible spectrophotometry using a single beam was done with the Shimadzu-UV mini 1240 instrument. Column chromatography was performed with silica gel 60G (70-230 mesh and 230-400 mesh). Thin-layer chromatography was performed with silica gel 60G F 254 using Merck (Art.5554), and spots were visualized by spraying with cerium sulfate vapours and ultraviolet light. Only analytical reagent grade solvents were used.

\section{Sample collection}

The fresh leaves of $P$. canescens were collected from the Musi Banyuasin Regency of South Sumatra, Indonesia in October 2019. The plant was identified as P. canescens Jack by Dr. Laila Hanum (Voucher specimen VIC 2704), head of the Botany Laboratory, University of Sriwijaya. The plant was deposited at the Botany Laboratory in the Biology Department at the University of Sriwijaya.

\section{Extraction and isolation}

The fresh leaves of P. canescens $(1.2 \mathrm{~kg}$ ) were extracted using the maceration method with step gradient polarity and using the solvents $n$-hexane and ethyl acetate. The leaves soaked for $3 \mathrm{~d}$ before filtration. This process (of maceration and filtration) was repeated three times. The filtrate was then concentrated using a vacuum rotary evaporator at about $60{ }^{\circ} \mathrm{C}$ and obtained a crude n-hexane extract and ethyl acetate extract [13]. The crude $n$-hexane extract $(15.97 \mathrm{~g})$ was separated using vacuum column chromatography with silica gel 60G (230-400 mesh) as the stationary phase. Samples were prepared by pre-adsorption using silica gel 60G (70-230 mesh) and dried to form a powder. The sample was eluted with solvent in increasing proportions of ethyl acetate in $n$-hexane 10:0 $(300 \mathrm{ml})$, 
9:1 (400 ml), 8:2, $(400 \mathrm{ml}), 5: 5(300 \mathrm{ml}), 4: 6(300 \mathrm{ml})$, and 0:10 (300 $\mathrm{ml})$. The eluent was placed in bottles $(500 \mathrm{ml})$. Each bottle was analyzed using thin-layer chromatography (TLC) using a mobile phase with a 7:3 ratio of $n$-hexane to ethyl acetate. Eluents that showed the same TLC patterns were combined and concentrated to a minimum volume and obtained the fractions F1 (1.64 g), F2 (1.22 g), F3 (1.35 g), F4 (2.88 g), and F5 (2.49 g). The F4 fraction ( $3.25 \mathrm{~g})$ was separated and purified using open column chromatography and silica gel 60G (70-230 mesh) as the stationary phase [14]. Samples were also prepared by pre-adsorption. The column was first eluted with $n$-hexane and then with the solvent that was prepared by gradually increasing the percentage of ethyl acetate in $n$-hexane. The ratios of $n$-hexane to ethyl acetate that were use: 9:1 $(300 \mathrm{ml}), 8: 2$ $(400 \mathrm{ml}), 7: 3(100 \mathrm{ml}), 6: 4(150 \mathrm{ml}), 5: 5(100 \mathrm{ml})$, and ethyl acetate $100 \%$ (300 ml). Eluates were collected in bottles $(10 \mathrm{ml})$, and each bottle was analyzed using TLC. The eluates that showed the same TLC patterns were combined and concentrated to a minimum volume and four subfractions F4.1 (0.339 g), F4.2 (0.520 g), F4.3 $(0.225 \mathrm{~g})$, and F4.4 $(0.539 \mathrm{~g})$ were obtained. The F4.3 fraction indicated the formation of a white solid, and after purification with ethyl acetate, obtained a white amorphous solid 1 (8.5 mg).

The ethyl acetate extract ( $30 \mathrm{~g}$ ) was then separated using vacuum column chromatography with increasing ethyl acetate proportions in $n$-hexane (10:0-0:10) as mobile phase, each with a volume of 300 $\mathrm{ml}$. The eluents that showed the same TLC pattern were pooled and concentrated to a minimum volume and obtained three fractions F1 (4.72 g), F2 (3.27 g), and F3 (17.18 g). The F2 (3.27 g) fraction was separated using open column chromatography with silica gel G60 (70-230 mesh) as the stationary phase. Solvents were made by increasing concentrations of ethyl acetate in $n$-hexane. The ratios of $n$-hexane to ethyl acetate that were used: 10:0 (200 ml), 9:1 (200 $\mathrm{ml}), 8: 2(300 \mathrm{ml}), 5: 5(300 \mathrm{ml})$, and ethyl acetate $100 \%(300 \mathrm{ml})$. Eluates were analyzed using TLC. Eluates that showed combined the same TLC pattern, and obtained five subfractions F2.1 ( $0.325 \mathrm{~g}$ ), F2.2 (0.855 g), F2.3 (0.112 g), F2.4. (0.720 g), and F2.5 (1.02 g). Fraction F2.3 was a greenish-white solid, and after recrystallization in $n$ hexane, obtained a white amorphous solid 2 (12 mg). The compound that was isolated was analyzed using TLC with eluents with different polarities, and spots were visualized by spraying with cerium sulfate vapour to verify that it was a pure compound. Furthermore, IR and 1D NMR spectroscopic analysis was performed on the compounds that were isolated.

\section{Anticholesterol activity}

The anticholesterol activity of the compounds was determined using photometry. Cholesterol reacts with the Liebermann-Burchard reagent [15]. Simvastatin was used as a positive control. The concentrations of the compounds that were isolated and simvastatin that were used: $10,20,30,40,50,75$, and $100 \mu \mathrm{g} / \mathrm{ml}$. Samples $(2.5$ $\mathrm{ml}$ ) were tested by the addition of $2.5 \mathrm{ml}$ cholesterol standard 100 $\mu \mathrm{g} / \mathrm{ml}$ and then shaken for $2 \mathrm{~min}$ and combined with $2 \mathrm{ml}$ of acetic anhydride and $0.1 \mathrm{ml}$ of sulfuric acid. Left the mixture was left for 16 $\mathrm{min}$ at room temperature. The measurements were done three times. As a control, they were using cholesterol $100 \mu \mathrm{g} / \mathrm{ml}$. The absorbance data measured at $\lambda_{\operatorname{maxs}} 420 \mathrm{~nm}$. Calculated the percentage of inhibition was calculated with the formula:

$$
\% \text { Inhibition }=\text { Ao-As } / \text { Ao } \times 100
$$

Ao: absorbance control and As: absorbance sample

\section{RESULTS AND DISCUSSION}

Extraction of fresh leaves of $P$. canescens $(1.2 \mathrm{~kg}$ ) with a solvent ( $n$ hexane and ethyl acetate) and evaporation to dryness under a high vacuum at about $60^{\circ} \mathrm{C}$, produced a crude $n$-hexane extract $(15.97 \mathrm{~g})$ and ethyl acetate $(62.69 \mathrm{~g})$, with yield percentages $1.33 \%$ and $5.22 \%$ respectively. The yield percentages demonstrated that the ethyl acetate fraction was greater in quantity than the $n$-hexane fraction because ethyl acetate is a semipolar solvent that can attract nonpolar and polar compounds. The $n$-hexane extract $(15.97 \mathrm{~g}$ ) was separated and purified using a chromatography column to obtain a white, amorphous solid (1) (8.5 mg). The ethyl acetate extract was separated and purified to obtain a white amorphous solid (2) (12 mg). Performed spectroscopic analysis (IR and NMR 1D) to determine the compound's molecular structures that were isolated. FTIR spectrometer was recorded on between the range 3500-1000 $\mathrm{cm}^{-1}$. The wavelength of light absorbed is characteristic of the chemical bonds [16]. The IR spectrum for the compound (1) had absorption bands at $2966 \mathrm{~cm}^{-1}$ and $2880 \mathrm{~cm}^{-1}$ (C-H aliphatic stretching in the form of $\mathrm{CH}_{3}, \mathrm{CH}_{2}$ and $\mathrm{CH}$ groups) and absorption frequencies at $1156 \mathrm{~cm}^{-1}$ (C-O) and $1774 \mathrm{~cm}^{-1}$ ( $\mathrm{C}=0$ acid). The IR spectrum also had absorption bands at $1661 \mathrm{~cm}^{-1}$ ( $\mathrm{C}=\mathrm{C}$ isolated), $1468 \mathrm{~cm}^{-1}$ (cyclic $\left(\mathrm{CH}_{2}\right) \mathrm{n}$ bending), and $1392 \mathrm{~cm}^{-1}$ (gem-dimethyl$\left.\mathrm{CH}\left(\mathrm{CH}_{3}\right)_{2}\right)$. The IR spectrum of the compound had several vibrations characteristic of the triterpenoid compound.

The ${ }^{1} \mathrm{H}$ NMR spectrum of the compound (1) (fig. 1) showed no absorption in the $\delta_{\mathrm{H}}$ 6-8 ppm region, which indicated that the compound was cycloaliphatic and a number of the terpenoid group. The shielded region of the spectrum indicated overlapping resonances for methylene and methine protons. ${ }^{1} \mathrm{H}$ NMR $\left(\mathrm{CD}_{3} \mathrm{OD}\right.$, $125 \mathrm{MHz}) \delta_{\mathrm{H}}$ ppm values and ${ }^{13} \mathrm{C}$ NMR $(500 \mathrm{MHz}) \delta_{\mathrm{c}}$ ppm values of the compound is shown in table 1 . The ${ }^{1} \mathrm{H}$ NMR spectrum of the compound showed resonances for methylene olefinic protons at $\delta_{\mathrm{H}}$ $4.71(1 \mathrm{H}, d, J=2.5 \mathrm{~Hz})$ and $4.59(\mathrm{H}, d, J=2.5 \mathrm{~Hz})$. The peak at $\delta_{\mathrm{H}} 4.62$ $(1 \mathrm{H}, s)$ was the $\mathrm{H}$ bond signal to the oxygen atom $(\mathrm{OH})$. The proton ${ }^{1} \mathrm{H}$ NMR spectrum showed the proton $\mathrm{H}-3$ appeared at $\delta_{\mathrm{H}}$ $3.13 \mathrm{ppm}(1 \mathrm{H}, \mathrm{m})$ as an oxymethine proton. Six singlet signals with strong intensities with chemical shift values of $\delta_{\mathrm{H}} 0.75(3 \mathrm{H}, s), 0.86$ $(3 \mathrm{H}, s), 0.95(3 \mathrm{H}, s), 0.96(3 \mathrm{H}, s), 1.00(3 \mathrm{H}, s)$, and $1.69(3 \mathrm{H}, s)$ that are characteristic signals of methyl proton in triterpenoid were also obtained. The ${ }^{1} \mathrm{H}$ NMR spectrum methyl proton signal at $\delta_{\mathrm{H}} 1.69$ $\mathrm{ppm}$ is the typical signal for methyl allylic proton [17]. The ${ }^{1} \mathrm{H}$ NMR spectrum of compound 1 contained only six methyl groups instead of eight, which is expected for a triterpene. Since converted one of the methyl group into an olefin, the remaining methyl group must have been oxidized into a carboxylic acid. This was confirmed using the ${ }^{13} \mathrm{C}$ NMR spectrum of the compound (table 1), which resonated with the carboxylic acid at $\delta 180.2 \mathrm{ppm}$. These resonances are typical of triterpenes with olefin, hydroxyl, and carboxylic acid functional groups but did not detect the carboxylic acid proton in the ${ }^{1} \mathrm{H}$ NMR spectrum.

The ${ }^{13} \mathrm{C}$ NMR spectrum (in $\mathrm{CD}_{3} \mathrm{OD}$ ) (fig. 2) showed 30 carbon signals (table 1). Resonance for the oxymethine carbon $\left(\delta_{c} 79.8\right)$, which is commonly found in triterpenoid compounds, and olefinic carbons $(\delta \mathrm{c}$ 152.1 and $\delta_{c} 110.4$ ) were also detected (fig. 2). The remaining 26 carbon resonances were attributed to the methyl, methylene, methane, and quaternary carbons. The DEPT spectrum, the compound showed seven quaternary carbon signals with chemical shifts at $\delta_{c} 180.2$, $152.1,38.4,42.0,40.0,39.8$, and $57.6 \mathrm{ppm}$; five-carbon methine signals at $\delta_{\mathrm{c}} 79.7,56.9,52.1,50.2$, and $48.6 \mathrm{ppm} ; 11$ methylene signals at $\delta_{\mathrm{c}}$ $38.2,28.1,19.6,35.7,22.2,26.9,30.9,31.8,33.4,40.2,110.3 \mathrm{ppm}$; and six methyl signals at $\delta c 28.7,19.5,16.2,16.8,16.7$, and $15.2 \mathrm{ppm}$.

The NMR spectrum data for compound 1 was compared with data in the literature. Based on the literature, the ${ }^{1} \mathrm{H}-\mathrm{NMR}$ and ${ }^{13} \mathrm{C}-\mathrm{NMR}$ data of the compounds show great similarities with betulinic acid, as shown in table 1 [18]. Based on the IR, ${ }^{1} \mathrm{H}$ NMR, and ${ }^{13} \mathrm{C}$ NMR spectroscopic data analysis, and by comparing with the data in the literature, compound 1 found to be betulinic acid (fig 3). This is the first report on the isolation of the compound from P. canescens. Betulinic acid is a pentacyclic triterpene found in many plant species including in the bark of Dillenia kerrii [19] and Dillenia papuana [20]. Betulinic acid has also been found in Dillenia philippinensis and has active antibacterial properties [17]. Betulinic acid has also been reported to display various biological activity, including anticancer activity [21] and anti-HIV agent [22, 23].

Compound 2 was a white amorphous solid. The IR spectrum of compound 2 in the $\mathrm{KBr}$ pellet showed some characteristic absorptions at $3410 \mathrm{~cm}^{-1}$ (OH group), $2935 \mathrm{~cm}^{-1}$, and $2868 \mathrm{~cm}^{-}$ ${ }^{1}$ (aliphatic stretching- $\mathrm{CH}$ asymmetric and symmetric). Other peaks were seen at $1624 \mathrm{~cm}^{-1}(\mathrm{C}=\mathrm{C}), 1480 \mathrm{~cm}^{-1}$, and $1377.17 \mathrm{~cm}^{-1}$ (cyclic bending of $\left(\mathrm{CH}_{2}\right)_{\mathrm{n}}$ and $\left.\left(\mathrm{CH}_{3}\right)_{2} \mathrm{CH}\right)$. There were also peaks at 1043 $\mathrm{cm}^{-1}$ (C-O alcoholic) and $970 \mathrm{~cm}^{-1}$ (unsaturated-CH vibration). The ${ }^{1} \mathrm{H}$ NMR chemical shifts at $\delta_{\mathrm{H}} 5.35(1 \mathrm{H}, d, J=6.0 \mathrm{~Hz}), 5.05(1 \mathrm{H}$, $d d, J=8.5,15 \mathrm{~Hz})$, and $4.95(1 \mathrm{H}, d d, J=8.5,15 \mathrm{~Hz})$ were the three 
olefinic proton shifts characteristic of stigmasterol. The chemical shifts at $\delta_{\mathrm{H}} 3.32 \mathrm{ppm}(1 \mathrm{H}, \mathrm{m})$ indicated oxymethine protons, which is characteristic of steroid compounds that contain $\mathrm{OH}$ groups bound to $\mathrm{C}-3$. The ${ }^{1} \mathrm{H}$ NMR spectrum also showed a strong intensity signal that are characteristic signals of methyl protons. The doublet signal at $0.81,0.83,0.85 \mathrm{ppm}$ and integration of three protons for signal methyl. This is a characteristic signal for methyl groups in stigmasterol compound. The two singlet signals from methyl atom at $\delta_{\mathrm{H}} 0.73$ and $1.02 \mathrm{ppm}(3 \mathrm{H}, \mathrm{s})$ are characteristic signals for the methyl position $\mathrm{C}-18$ and $\mathrm{C}-19$ in stigmasterol.

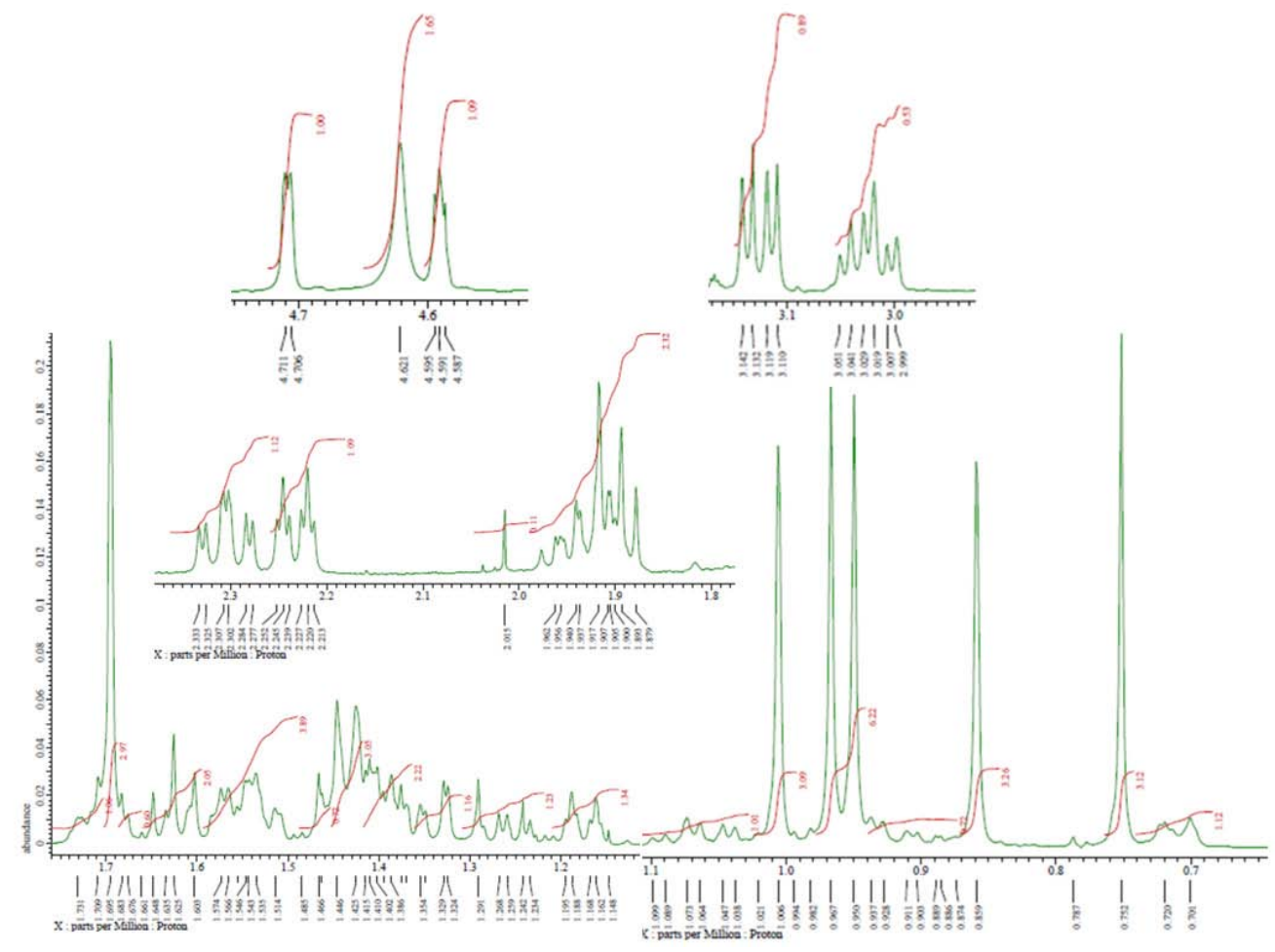

Fig. 1: ${ }^{1}$ H NMR Betulinic acid (1)

Table 1: ${ }^{1} \mathrm{H}$ and ${ }^{13} \mathrm{C}$ NMR spectral chemical shift values for compound $1\left({ }^{1} \mathrm{H}-500 \mathrm{MHz},{ }^{13} \mathrm{C}-125 \mathrm{MHz}\right.$, in $\left.\mathrm{CD}{ }_{3} \mathrm{OD}\right)$ and betulinic acid [18] ( ${ }^{1} \mathrm{H}-$ $400 \mathrm{MHz}^{13} \mathrm{C}-100 \mathrm{MHz}$, in $\mathrm{CDCl}_{3}, \mathrm{ppm}$ )

\begin{tabular}{|c|c|c|c|c|c|}
\hline $\mathrm{C}$ & $\delta_{C}[18]$ & $\boldsymbol{\delta}_{\mathrm{C}} \mathbf{1}$ & $\delta_{\mathrm{H}}$ mult. $(\mathrm{Hz})[18]$ & $\delta_{\mathrm{H}}$, mult. $(\mathrm{Hz}) 1$ & DEPT \\
\hline 1 & 38.7 & 38.2 & $0.90,1.69$ & & $\mathrm{CH}_{2}$ \\
\hline 2 & 27.4 & 28.1 & $1.55,1.62$ & & $\mathrm{CH}_{2}$ \\
\hline 3 & 79.0 & 79.7 & $3.20 d d(4.5,11.5)$ & $3.13(d d, 5.0,10.5)$ & $\mathrm{CH}$ \\
\hline 4 & 38.9 & 38.4 & - & & $\mathrm{C}$ \\
\hline 5 & 55.3 & 56.9 & 0.68 & & $\mathrm{CH}$ \\
\hline 6 & 18.3 & 19.6 & 1.53 & & $\mathrm{CH}_{2}$ \\
\hline 7 & 34.3 & 35.7 & 1.40 & & $\mathrm{CH}_{2}$ \\
\hline 8 & 40.7 & 42.0 & - & & $\mathrm{C}$ \\
\hline 9 & 50.5 & 52.1 & 1.26 & & $\mathrm{CH}$ \\
\hline 10 & 37.2 & 40.0 & - & & $\mathrm{C}$ \\
\hline 11 & 20.8 & 22.2 & $1.41,1.43$ & & $\mathrm{CH}_{2}$ \\
\hline 12 & 25.5 & 26.9 & $1.66,1.68$ & & $\mathrm{CH}_{2}$ \\
\hline 13 & 38.4 & 39.8 & 2.20 & & $\mathrm{CH}$ \\
\hline 14 & 42.4 & 43.7 & - & & $\mathrm{C}$ \\
\hline 15 & 29.7 & 30.9 & $1.22,1.55$ & & $\mathrm{CH}_{2}$ \\
\hline 16 & 32.1 & 31.8 & $1.42,2.30$ & & $\mathrm{CH}_{2}$ \\
\hline 17 & 56.3 & 57.6 & - & & $\mathrm{C}$ \\
\hline 18 & 49.3 & 50.2 & 1.62 & & $\mathrm{CH}$ \\
\hline 19 & 46.9 & 48.6 & $3.02 d t(10.5,5.5)$ & $3.02(\mathrm{~m})$ & $\mathrm{CH}$ \\
\hline 20 & 150.4 & 152.1 & - & & $\mathrm{C}$ \\
\hline 21 & 30.5 & 33.4 & $1.41,1.99$ & & $\mathrm{CH}_{2}$ \\
\hline 22 & 37.0 & 40.2 & $1.48,1.96$ & & $\mathrm{CH}_{2}$ \\
\hline 23 & 27.9 & 28.7 & $0.95(s)$ & $0.96(s)$ & $\mathrm{CH}_{3}$ \\
\hline 24 & 15.3 & 16.2 & $0.74(s)$ & $0.75(s)$ & $\mathrm{CH}_{3}$ \\
\hline 25 & 16.1 & 16.8 & $0.80(s)$ & $0.86(s)$ & $\mathrm{CH}_{3}$ \\
\hline 26 & 16.0 & 16.7 & $0.92(s)$ & $0.95(s)$ & $\mathrm{CH}_{3}$ \\
\hline 27 & 14.7 & 15.2 & $0.96(s)$ & $1.00(s)$ & $\mathrm{CH}_{3}$ \\
\hline 28 & 179.8 & 180.2 & - & & $\mathrm{C}$ \\
\hline 29 & 109.7 & 110.3 & $4.62 d(2.0), 4.70 d(2.0)$ & $4.71 d(2,5) 4.59 d(2.5)$ & $\mathrm{CH}_{2}$ \\
\hline 30 & 19.4 & 19.5 & $1.69(s)$ & $1.69(s)$ & $\mathrm{CH}_{3}$ \\
\hline
\end{tabular}




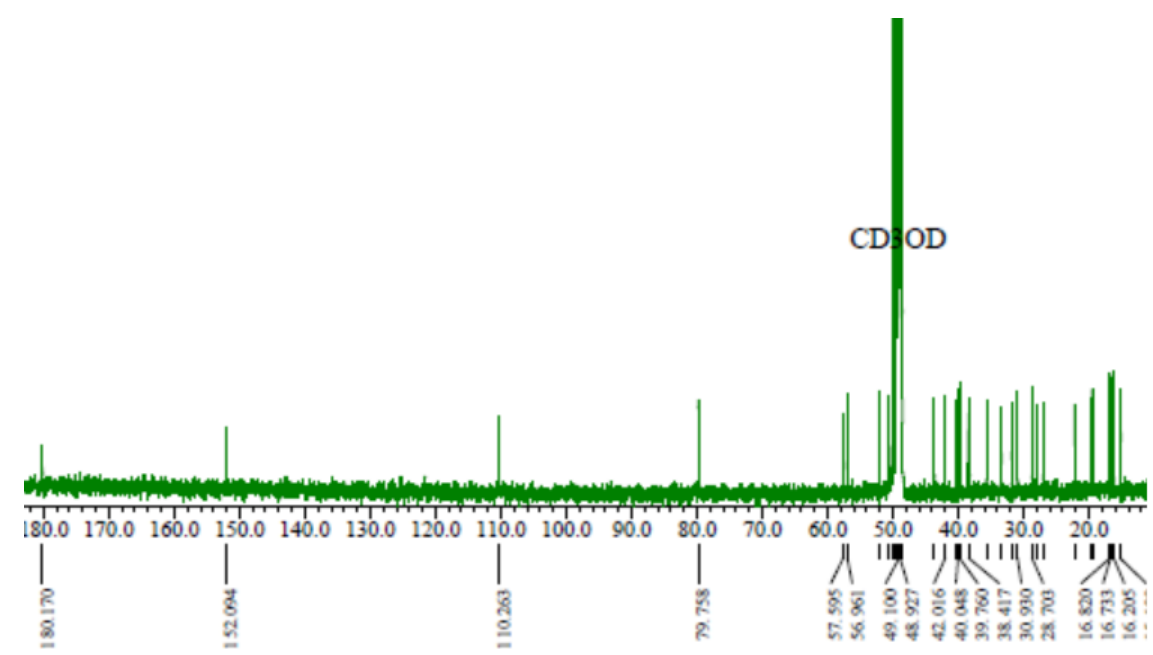

Fig. 2: ${ }^{13} \mathrm{C}$ NMR betulinic acid (1)

Table 2: ${ }^{1} \mathrm{H}$ and ${ }^{13} \mathrm{C}$ NMR spectral chemical shift values (ppm) for compound $2\left({ }^{1} \mathrm{H}-500 \mathrm{MHz},{ }^{13} \mathrm{C}-125 \mathrm{MHz}\right)$, and stigmasterol ( ${ }^{1} \mathrm{H}-400$ $\mathrm{MHz},{ }^{13} \mathrm{C}-100 \mathrm{MHz}$, in $\left.\mathrm{CDCl}_{3}, \mathrm{ppm}\right)[24]$

\begin{tabular}{|c|c|c|c|c|c|}
\hline $\mathbf{C}$ & $\delta_{\mathrm{C}}$ stigmasterol [24] & $\boldsymbol{\delta}_{\mathrm{c}} 2$ & $\delta_{\mathrm{H}}(\mathrm{ppm}), \Sigma \mathrm{H}$, mult. $(\mathrm{Hz})$, stigmasterol [24] & $\delta_{H}(p p m), \Sigma H$, mult. $(J \mathrm{~Hz}), 2$ & DEPT \\
\hline 1 & 37.3 & 38.6 & & & $\mathrm{CH}_{2}$ \\
\hline 2 & 28.3 & 29.4 & & & $\mathrm{CH}_{2}$ \\
\hline 3 & 71.9 & 72.5 & $3.52(1 \mathrm{H}, d d)$ & $3.32(1 \mathrm{H}, m)$ & $\mathrm{CH}$ \\
\hline 4 & 42.4 & 43.1 & & & $\mathrm{CH}_{2}$ \\
\hline 5 & 140.8 & 142.3 & & & $\mathrm{C}$ \\
\hline 6 & 121.7 & 122.3 & $5.34(1 \mathrm{H}, d)$ & $5.35(1 \mathrm{H}, d, 6.0)$ & $\mathrm{CH}$ \\
\hline 7 & 31.7 & 33.1 & & & $\mathrm{CH}_{2}$ \\
\hline 8 & 34.0 & 33.3 & & & $\mathrm{CH}$ \\
\hline 9 & 50.2 & 51.8 & & & $\mathrm{CH}$ \\
\hline 10 & 36.5 & 37.7 & & & $\mathrm{C}$ \\
\hline 11 & 26.2 & 27.2 & & & $\mathrm{CH}_{2}$ \\
\hline 12 & 39.8 & 41.2 & & & $\mathrm{CH}_{2}$ \\
\hline 13 & 42.4 & 43.5 & & & $\mathrm{C}$ \\
\hline 14 & 56.8 & 57.5 & & & $\mathrm{CH}$ \\
\hline 15 & 24.3 & 24.2 & & & $\mathrm{CH}_{2}$ \\
\hline 16 & 29.2 & 32.3 & & & $\mathrm{CH}_{2}$ \\
\hline 17 & 56.1 & 58.2 & & & $\mathrm{CH}$ \\
\hline 18 & 12.0 & 12.5 & $0.67(3 \mathrm{H}, s)$ & $0.73(3 \mathrm{H}, s)$ & $\mathrm{CH}_{3}$ \\
\hline 19 & 19.4 & 19.4 & $1.00(3 \mathrm{H}, s)$ & $1.02(3 \mathrm{H}, s)$ & $\mathrm{CH}_{3}$ \\
\hline 20 & 40.5 & 37.5 & & & $\mathrm{CH}$ \\
\hline 21 & 21.1 & 20.3 & & & $\mathrm{CH}_{3}$ \\
\hline 22 & 138.3 & 139.9 & $5.16(1 \mathrm{H}, d d, 8.4,15)$ & $5.05(1 \mathrm{H}, d d, 8.5,15)$ & $\mathrm{CH}$ \\
\hline 23 & 129.0 & 130.0 & $5.03(1 \mathrm{H}, d d, 8.4,15)$ & $4.95(1 \mathrm{H}, d d, 8.5 ; 15)$ & $\mathrm{CH}$ \\
\hline 24 & 51.3 & 52.9 & & & $\mathrm{CH}$ \\
\hline 25 & 45.9 & 47.3 & & & $\mathrm{CH}$ \\
\hline 26 & 19.4 & 19.5 & $0.81(3 \mathrm{H}, d)$ & $0.83(3 \mathrm{H}, d)$ & $\mathrm{CH}_{3}$ \\
\hline 27 & 19.8 & 19.9 & $0.79(3 \mathrm{H}, d)$ & $0.81(3 \mathrm{H}, d)$ & $\mathrm{CH}_{3}$ \\
\hline 28 & 24.3 & 25.4 & & & $\mathrm{CH}_{2}$ \\
\hline 29 & 12.3 & 12.4 & $0.85(3 \mathrm{H}, d)$ & $0.86(3 \mathrm{H}, d)$ & $\mathrm{CH}_{3}$ \\
\hline
\end{tabular}

The ${ }^{13} \mathrm{C}$ NMR spectrum showed four signals above $100 \mathrm{ppm}$ (142.3, $139.9,130.0$, and $122.5 \mathrm{ppm})$. The signals at $\delta_{\mathrm{c}} 142.3$ and $130.0 \mathrm{ppm}$ were characteristic of $\mathrm{C}-22$ and $\mathrm{C}-23$ in stigmasterol [24]. The presence of four $\mathrm{sp}^{2}$ hybridized carbon signals indicated that the isolated compound had two double bonds. The ${ }^{13} \mathrm{C}$ NMR spectrum also showed a signal at $\delta \mathrm{c} 71.3 \mathrm{ppm}$, which is the signal for $\mathrm{sp}^{3}$ hybridized carbon, a typical signal for $\mathrm{C}-3$ atoms. The ${ }^{13} \mathrm{C}$ NMR spectrum for compound $\mathbf{2}$ showed 29 carbon signals. DEPT spectrum was used to determine the type of carbon (methyl, methylene, methine or quaternary carbon). The DEPT spectrum revealed six methyl groups at $\delta_{\mathrm{c}} 12.4,12.5,19.4,19.5,19.9$, and 20.3 ppm; nine methylene groups at $\delta_{\mathrm{c}} 24.2,25.5,27.2,29.4,32.2,33.1$, $38.6,41.2$, and $43.1 \mathrm{ppm} ; 11$ methine groups at $\delta \mathrm{c} 72.5,130.0,139.9$, $122.3,51.8,52.9,57.5,58.2,47.3,37.5$, and $33.3 \mathrm{ppm}$; and three quaternary carbons at $\delta \mathrm{c} 142.3,37.7$, and $43.5 \mathrm{ppm}$.
The NMR data of compound 2 was compared with data in the literature (table 2). The compound's chemical shift values were almost identical to those of the ${ }^{13} \mathrm{C}$ NMR spectrum of the stigmasterol compound found in the literature [24]. The Chloroform was used as the solvent for the measurements of both the compound and stigmasterol. The little difference in the value of the chemical shifts seen in the spectrum for the compound that was isolated and for stigmasterol found in the literature is probably due to the differences in the instrumentation used. The ${ }^{13} \mathrm{C}$-NMR spectral measurement of the compound was isolated at $500 \mathrm{MHz}$, while that of stigmasterol was done at $400 \mathrm{MHz}$ [24]. Based on the analysis of spectroscopic data IR and1D NMR spectral data, and using data found in the literature for stigmasterol, the compound $\mathbf{2}$ was found to be stigmasterol. Its structure is shown in fig. 3. 

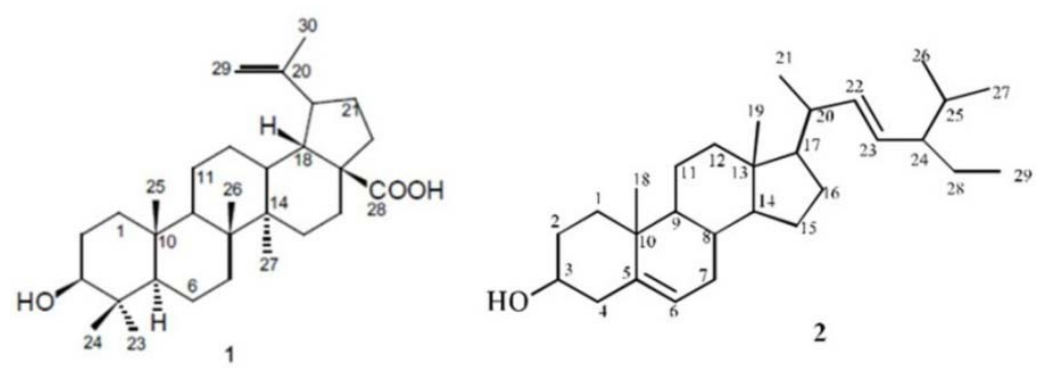

Fig. 3: Structure compounds betulinic acid (1) and stigmasterol (2)

\section{Anticholesterol test using the liebermann-burchard method}

The anticholesterol activity was determined by reacting cholesterol with the Liebermann-Burchard reagent. Simvastatin was used as a positive control in this experiment. Measurements were made at $\lambda_{\operatorname{maxs}} 420 \mathrm{~nm}$. The anticholesterol activity was determined based on the amount of residual cholesterol and calculated based on the percentage inhibition cholesterol. The higher the sample concentration, the smaller the absorbance value and a lower amount of cholesterol residue indicate higher anticholesterol activity.

Table 3: Percentage inhibition (\%I) cholesterol

\begin{tabular}{llll}
\hline Concentration $(\boldsymbol{\mu g} / \mathbf{m l})$ & \% Inhibition & Stigmasterol (2) & Simvastatin \\
\cline { 2 - 4 } & Betulinic acid (1) & $24.7 \pm 3.4$ & $86.8 \pm 0.3$ \\
\hline 100 & $71.9 \pm 3.9$ & $20.0 \pm 5.4$ & $72.1 \pm 0.1$ \\
75 & $63.2 \pm 0.9$ & $15.3 \pm 1.5$ & $57.6 \pm 2.3$ \\
50 & $50.71 \pm 1.2$ & $12.7 \pm 2.5$ & $54.6 \pm 0.1$ \\
40 & $41.2 \pm 3.0$ & $11.3 \pm 3.5$ & $51.2 \pm 0.2$ \\
30 & $29.9 \pm 2.5$ & $9.3 \pm 2.7$ & $48.3 \pm 0.2$ \\
20 & $12.1 \pm 3.4$ & $5.7 \pm 2.2$ & $47.6 \pm 0.2$ \\
10 & $7.84 \pm 1.7$ & & \\
\hline
\end{tabular}

Note: The data was given as mean $\pm \mathrm{SD} ; \mathrm{n}=3$

Table 4: The anticholesterol activity of the compounds

\begin{tabular}{ll}
\hline Compounds & $\mathbf{I C}_{\mathbf{5 0}}(\boldsymbol{\mu \mathbf { g }} / \mathbf{m l})$ \\
\hline Betulinic acid (1) & 60.53 \\
Stigmasterol (2) & 222.32 \\
Simvastatin & 24.68 \\
\hline
\end{tabular}

Based on the absorbance value, the percent inhibition value can be calculated (table 3). A higher percent inhibition value indicates a higher activity. At the same concentrations, the compounds that were isolated showed a lower percent inhibition value than simvastatin. Percent inhibition of the stigmasterol (2) is significantly lower than that of betulinic acid (1). The IC50 values for the compounds and the positive control simvastatin were determined using a regression equation of the relationship between concentration (x) and percentage inhibition cholesterol (y). The IC50 value was inversely proportional to the anticholesterol activity. The smaller the IC50 value, the higher the anticholesterol activity. Based on the linear regression equation, the IC50 value for betulinic acid (1) was $60.53 \mu \mathrm{g} / \mathrm{ml}$, and stigmasterol (2) $222.32 \mu \mathrm{g} / \mathrm{ml}$, while positive control simvastatin $24.68 \mu \mathrm{g} / \mathrm{ml}$ (table 4). The anticholesterol activity of stigmasterol (2) is deficient compared betulinic acid (1), while betulinic acid (1) active anticholesterol but lower anticholesterol activity than simvastatin.

Several other triterpenoid compounds have been reported to have anticholesterol properties. The triterpenoid compounds, $3 \beta$-hydroxyolean-12-en-28-at acid and 3,19-dihydroxy-urs-12-en-28-at acid found in the Saurauia vulcani Korth, showed anticholesterol activity [15]. Kedaung (Parkia timoriana (DC) Merr) was also found to contain two phytosterol compounds, $\beta$-sitosterol and campesterol, which can reduce total blood cholesterol and LDL levels $30-50 \%$ by inhibiting cholesterol absorption in the intestinal lumen [25].

\section{CONCLUSION}

In this study, the triterpenes betulinic acid (1) and the steroid stigmasterol (2) were isolated from the leaves of P. canescens. Betulinic acid (1) had an anticholesterol activity with $\mathrm{IC}_{50}$ of 60.53 $\mu \mathrm{g} / \mathrm{ml}$. This is the first report on the isolation of betulinic acid from $P$. canescens and the identification of its anticholesterol activity. The stigmasterol (2) has previously been reported from P. canescens

\section{ACKNOWLEDGEMENT}

The authors are thankful to the University of Sriwijaya Indonesia for funding this research Professional excellent Research Grant Program 2020, contract no $0174.07 / \mathrm{UN} 9 / \mathrm{SB} 3$. LPPM. PT/2020 and to the Department of Chemistry at the University of Sriwijaya for the facilities provided.

\section{AUTHORS CONTRIBUTIONS}

All the authors have contributed equally.

\section{CONFLICT OF INTERESTS}

The authors declared no conflict of interest

\section{REFERENCES}

1. Thomas ANS. Traditional medicinal plant. Yogyakarta, Kanisius; 1993.

2. Kusriani RH, Nawawi A, Turahman T. Antibacterial activity test extract and fractions the stem bark and leaves of sungkai (Peronema Canescens Jack) Staphylococcus aureus ATCC 25923 and Escherichia coli ATCC 25922. J Pharm Galenika 2015;2:8-14.

3. Yani AP, Putranto MH. Examination of the sungkai's young leaf extract (Peronema canescens) as an antipyretic, immunity, antiplasmodial and teratogenicity in mice (Mus musculus). Int J Sci Eng 2014;7:30-4. 
4. Yustian I, Muharni, Zulaicha S, Arbi M. Special research on the exploration of ethnomedicine and local community medicinal plants in Indonesia (Ethnic Musi II). Palembang. Ministry of Health Republic of Indonesia; 2012.

5. Ray S. Protective role of n-propyl gallate on docetaxel-induced changes in cholesterol profile. Int J Pharm Pharm Sci 2015;7:50-2.

6. Carmena R, Duriez P, Fruchart JC. Atherogenic lipoprotein particles in atherosclerosis. Circulation 2004;109:2-7.

7. Finn AV, Nakano M, Narula J, Kolodgie FD, Virmani R. Concept of vulnerable/unstable plaque. Arterioscler Thromb Vasc Biol 2010;30:1282-92

8. Prasiwi D, Sundaryono A, Handayani D. Activity of ethanol fraction from peronema canescens leaf extract on growth rate of plasmodium berghei. J Education Chem 2018;2:25-32.

9. Ibrahim A, Kuncoro H. Identification secondary metabolites and antibacterial activity of sungkai (Peronema Canescens Jack.) leaf extract against some pathogenic bacteria. J Trop Pharm Chem 2012;2:8-18

10. Simanjuntak P. Chemical study of the glycoside compounds of the sungkai Peronema canescens (Verbenaceae). Ind J Appl Chem 1996;6:8-12.

11. Kitagawa I, Simanjuntak P, Hori K, Nagami B, Mahmud T, Shibuya $\mathrm{H}$, Kobayashi M. Indonesian medicinal plants. VII seven new clerodane-type diterpenoids, peronemins A2, A3, B1, B2, B3, C1 and D1 from the leaves of Peronema canescens (Verbenaceae). J Chem Pharm Bull 1994;42:1050-5.

12. Sitepu N. In vitro test of antibacterial ethanol extract, $n$-hexane fraction and ethyl acetate fraction of sungkai leaf (Peronema canescens) against Salmonella typhi. Asian J Pharm Res Dev 2020;8:57-60.

13. Ibrahim HA, Fatehia SE, Mahmoud E, Samah S, Eman GH Phytochemical screening and biological evaluation of dypsis leptocheilos leaves extract and molecular docking study of the isolated compounds. Int J Pharm Pharm Sci 2020;12:106-13.

14. Preethi NV, Vagdevi HM, Latha KP, Ajish AD. Phytochemical screening in vitro biological activities and isolation of active molecule from vitex altissima leaves. Asian J Pharm Clin Res 2020;13:96-100.

15. Musa WJA, Situmeang B, Sianturi J. Anti-cholesterol triterpenoid acids from Saurauia vulcani Korth. (Actinidiaceae) Int J Food Prop 2019;22:1439-44.

16. Divya BJ, Suman B, Venkataswany M, Thyagaraju K. A study on phytochemicals, functional groups and mineral composition of Allium sativum (garlic) cloves. Int J Curr Pharm Res 2017;9:42-5.

17. Ragasa CY, Alimboyoguen AB, Shen CC. Antimicrobial triterpenes from Dillenia philippinensis. Philip Scient 2009;46:78-87.

18. Khaliq S, Volk FJ, Frahm AW. Phytochemical investigation of Perovskia abrotanoides. Planta Med 2017;73:77-83.

19. Li X, Li CW, Cui CB, Li MM, Fan M. Chemical constituents of Dillenia kerrii and their activities on antitumor and antihypoxia in vitro. Chin J Med Chem 2009;19:130-4.

20. Nick A, Wright AD, Sticher O, Rali T. Antibacterial triterpenoid acids from Dillenia papuana. J Nat Prod 1994;57:1245-50.

21. Rzeski W, Stepulak A, Szymanski M, Sifringer M, Kakzor J, Wejksza K, et al. Betulinic acid decreases expression of bcl-2 and cyclin D1, inhibits proliferation, migration and induces apoptosis in cancer cells. Naunyn Schmiedebergs Arch Pharmacol 2006;374:11-20.

22. Hashimoto $\mathrm{F}$, Kashiwada $\mathrm{Y}$, Cosentino LM, Chan $\mathrm{CH}$, Garret PE, Lee KA. Anti-AIDS agents-XXVII. Synthesis and anti-HIV activity of betulinic acid and dihydrobetulinic acid derivatives. Bioorg Med Chem 1997;5:2133-43.

23. Cichewicz RH, Kouzi SA. Chemistry, biological activity, and chemotherapeutic potential of betulinic acid for the prevention and treatment of cancer and HIV infection. Med Res Rev 2004:24:90-114.

24. Ahmed Y, Rahman S, Akther P, Islam F, Rahman M, Yaakob Z. Isolation of steroids from $n$-hexane extract of the leaves of Saurauia roxburghii. Int Food Res J 2013;20:2939-43.

25. Tisnadjaja D, Hidayat SL, Sumirja S, Simanjuntak P. Study of phytosterol content of kedaung (Parkia roxburgii G. Don.) Biodiversitas 2006;7:21-4. 